\title{
Lipoprotein levels in apparently healthy men and women in the west of Scotland
}

\author{
J. S. Jubb, A. R. Lorimer, V. M. Hawthorne, H. G. Morgan, and T. D. V. Lawrie \\ From the University Departments of Pathological Chemistry and Medical Cardiology, Royal Infirmary, \\ and University Department of Community Medicine, Ruchill Hospital, Glasgow
}

Lipoprotein typing was undertaken in apparently healthy women (419) and men (103) in whom measurements of fasting total cholesterol, triglycerides, and cholesterol content of the major lipoprotein fractions were made.

In the female group (30 to 59 years) there was a significant rise in total cholesterol, low density lipoprotein ( $L D L)$ cholesterol, and triglycerides with age. Using total cholesterol and triglyceride levels for classification, type II hyperlipoproteinaemia was present in 1 per cent and type IV in 6.7 per cent. When LDL cholesterol levels were also considered, type II occurred in 9.8 per cent $(8.4 \%$ type IIA and $1.4 \%$ type IIB).

In the male group (40 to 59 years) there was no increase in cholesterol or triglyceride levels with age: 11 per cent had type IV hyperlipoproteinaemia and none had a type II abnormality. When LDL cholesterol levels were also considered, type II occurred in 3 per cent (2\% type IIA and $1 \%$ type IIB).

The apparent increase in LDL cholesterol and frequency of type IIA abnormality in women could be merely the consequence of arbitrary selection of upper limits of normality for LDL cholesterol, but may signify improved detection of a high risk group.

Previous surveys have identified raised cholesterol and/or triglyceride concentrations as risk factors for coronary heart disease (Blackburn, 1970; Carlson and Böttiger, 1972). Prospective studies suggest that the degree of rise is of prognostic value (Carlson and Böttiger, 1972; Keys, 1970; Kannel et al., 1971). In addition, reports indicate that low density lipoprotein (LDL), as measured by its cholesterol content, may be a more important prognostic factor for coronary heart disease than total cholesterol (Slack, 1969).

An earlier study of 4496 apparently healthy male subjects at work in the west of Scotland showed that 15.3 per cent had a lipoprotein abnormality as indicated by a rise in plasma cholesterol and/or triglyceride. This study has been extended to assess the frequency of lipoprotein abnormalities when measured by LDL cholesterol levels, in addition to total cholesterol and triglycerides, in a group of female and male subjects.

Received 29 December 1975.

\section{Patients and methods}

The group consisted of 419 women and 103 men, whose ages ranged between 35 and 60 years. All worked in a light engineering factory and were distributed approximately equally between light manual and non-manual work. The response rate was 59.6 per cent.

Before attending the screening unit each subject was given a standardized questionnaire on history of chest pain (Rose and Blackburn, 1968a), smoking habits, and bronchitis (Medical Research Council, 1965). At the screening unit the procedure was as described by Hawthorne, Gillis, and McLean (1972): height, weight, blood pressure, and a standard six limb-lead electrocardiogram were recorded (Rose and Blackburn, 1968b).

After an overnight fast, $10 \mathrm{ml}$ blood were drawn, without venous stasis, into lithium sequestrene $(1 \mathrm{~g} / 1)$. Plasma was separated and stored at $4^{\circ} \mathrm{C}$ before analysis. Plasma total cholesterol and triglycerides were measured by autoanalyser techniques 
(Annan and Isherwood, 1969; Kessler and Lederer, 1965) and lipoprotein electrophoresis carried out on paper using albuminated buffer (Lees and Hatch, 1963). Those subjects whose electrophoretic pattern showed chylomicra were excluded. The cholesterol content of each major lipoprotein fraction of plasma was estimated by the precipitation technique of Burstein, Scholnick, and Morfin (1970). This technique had previously been compared with the ultracentrifugal fractionation method of Fredrickson, Levy, and Lees (1967). Plasma samples from 40 patients with a variety of lipoprotein levels were fractionated by both methods; the mean VLDL, LDL, and HDL cholesterol levels were similar for each method.

Initially each subject was assigned two phenotypes, using the upper limits of normal reported by Fredrickson et al. (1967) in a North American population, and the classification suggested by Beaumont et al. (1970). It was assumed that a rise in total cholesterol, alone, signified a raised LDL cholesterol. Similarly, a triglyceride level above the accepted limits signified a raised VLDL content in the plasma. No attempt was made to classify subjects with increases of both cholesterol and triglyceride. The additional data obtained from lipoprotein precipitation allowed a second phenotype to be assigned to each subject. A raised LDL cholesterol was indicative of type II hyperlipoproteinaemia. Subjects with raised total cholesterol and triglyceride were assessed on the basis of LDL cholesterol and classified as type IIB or type IV phenotype as appropriate. The classification and criteria are shown in Table 1.

In $65(11 \%)$ subjects there was insufficient plasma for precipitation of all fractions. In these subjects total cholesterol and VLDL cholesterol were measured, but a high density lipoprotein (HDL) cholesterol level of $1.3 \mathrm{mmol} / 1$ was assumed; LDL cholesterol was then calculated. ${ }^{1}$ In a series of $\mathbf{3 0 0}$ comparisons no significant difference was found in LDL cholesterol values obtained using a measured or 'assumed' HDL cholesterol value (Ballantyne and Jubb, in preparation).

Subjects with chylomicra in their plasma were assumed to be non-fasting and were excluded; this means that any type I and V subjects, together with the non-fasting population, have not been considered. There were three such subjects. Type III abnormality is rare and was not sought in this study.

\section{Normal and abnormal participants}

The total population was divided into four subgroups: female normal and abnormal, male normal and abnormal-according to the criteria used in our previous survey (Lorimer et al., 1974). Subjects were regarded as abnormal who were in one or more of the following categories: smoking more than 5 cigarettes per day; more than 10 per cent above ideal weight for age; hypertensive, i.e. systolic

${ }^{1}$ LDL cholesterol $=$ Total cholesterol-(VLDL cholesterol + 1.3) $\mathrm{mmol} / \mathrm{l}$.

TABLE 1 Criteria for establishing lipoprotein phenotypes

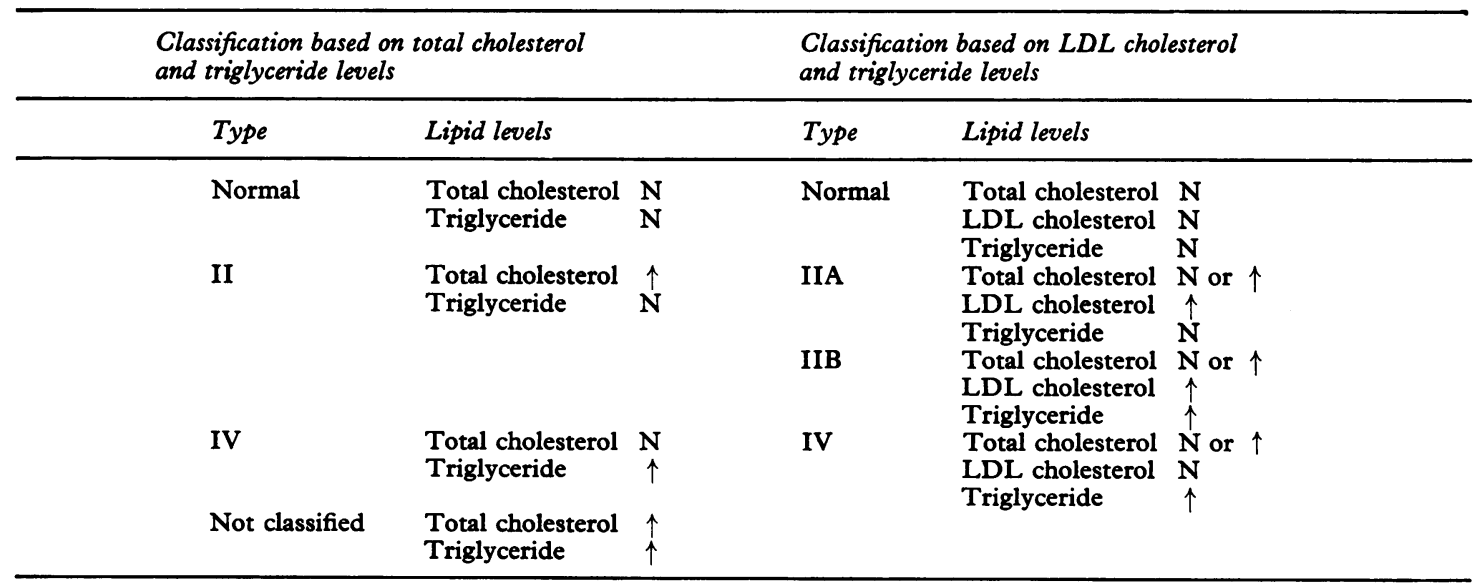

Notes: Subjects with chylomicra at origin on paper electrophoresis were excluded as non-fasting (or Type I or V). Type III has not been considered because of its rarity.

Abbreviations: $\mathrm{N}=$ normal; $\uparrow=$ raised. 
TABLE 2 Health survey in west of Scotland

\begin{tabular}{lll}
\hline Classification & Male (\%) & Female (\%) \\
\hline Normal & 17.5 & 30.4 \\
Abnormal & 79.5 & 69.6 \\
Non-fasting & 3.0 & - \\
\hline
\end{tabular}

blood pressure $>170 \mathrm{mmHg}$ or diastolic blood pressure $>100 \mathrm{mmHg}$; electrocardiographic abnormalities present (types I and II in Minnesota code); a history suggestive of angina or myocardial infarction. The number of subjects in each subgroup is shown in Table 2 .

\section{Results}

\section{Female population}

Fasting lipid levels were available in 419 female subjects (127 normal and 292 having one or more abnormality as previously defined). In these subgroups results for total cholesterol, LDL cholesterol, and triglyceride were considered in relation to age. These data are presented in Table 3. None of the subjects was taking an oral contraceptive agent at the time of sampling. The number of post-menopausal subjects is unknown.

In the total female population there was a significant rise in cholesterol, LDL cholesterol, and triglyceride with age. In addition, the triglyceride levels obtained in the abnormal group were significantly higher $(P<0.01)$ than in age-related 'normal' subjects. The 'abnormal' group includes those subjects who were obese, either as a single abnormality or together with other abnormalities. The obese, but otherwise normal group was small and could not be analysed independently.

These lipid values were used as the basis for typing of hyperlipoproteinaemia. The upper limits of normal used were those reported by Fredrickson
TABLE 4 Lipoprotein abnormalities in apparently healthy women

\begin{tabular}{|c|c|c|c|c|c|c|c|}
\hline \multirow[t]{2}{*}{$\begin{array}{l}\text { Age } \\
\text { group }\end{array}$} & \multirow[t]{2}{*}{$\begin{array}{l}\text { No. of } \\
\text { subjects }\end{array}$} & \multicolumn{2}{|c|}{$\begin{array}{l}\text { Classification by } \\
\text { total cholesterol } \\
\text { and triglyceride } \\
\text { Type II Type Total } \\
A \quad B \text { IV }\end{array}$} & \multicolumn{4}{|c|}{$\begin{array}{l}\text { Classification by } \\
\text { LDL cholesterol and } \\
\text { triglyceride* } \\
\text { Type II Type } \\
\begin{array}{lll}\text { Total } & \text { Ty IV }\end{array}\end{array}$} \\
\hline & & \multicolumn{5}{|c|}{ Total population } & \\
\hline $\begin{array}{l}30-39 \\
40-49 \\
50-59\end{array}$ & $\begin{array}{l}58 \\
188 \\
173\end{array}$ & $\begin{array}{l}3.5 \\
0.5 \\
0.6\end{array}$ & $\begin{array}{lrr}0 & 3.5 & 7.0 \\
0 & 9.1 & 9.6 \\
0 & 5.2 & 5.8 \\
\text { Normal } & \text { populat }\end{array}$ & $\begin{array}{r}3 \cdot 5 \\
9 \cdot 0 \\
9 \cdot 8 \\
\text { ion }\end{array}$ & $\begin{array}{l}1 \cdot 6 \\
1 \cdot 5 \\
1 \cdot 2\end{array}$ & $\begin{array}{l}3 \cdot 5 \\
7 \cdot 5 \\
4 \cdot 6\end{array}$ & $\begin{array}{r}8 \cdot 6 \\
18 \cdot 0 \\
15 \cdot 6\end{array}$ \\
\hline $\begin{array}{l}30-39 \\
40-49 \\
50-59\end{array}$ & $\begin{array}{l}21 \\
52 \\
54\end{array}$ & $\begin{array}{l}5 \cdot 0 \\
0 \\
1 \cdot 7\end{array}$ & $\begin{array}{llr}0 & 5.0 & 10.0 \\
0 & 3.3 & 3.3 \\
0 & 1.7 & 3.4\end{array}$ & $\begin{array}{r}5 \cdot 0 \\
3 \cdot 8 \\
9 \cdot 3\end{array}$ & $\begin{array}{l}5 \cdot 0 \\
1 \cdot 9 \\
1 \cdot 7\end{array}$ & $\begin{array}{l}0 \\
1 \cdot 9 \\
1 \cdot 7\end{array}$ & $\begin{array}{r}10 \cdot 0 \\
7 \cdot 6 \\
12 \cdot 7\end{array}$ \\
\hline $\begin{array}{l}30-39 \\
40-49 \\
50-59\end{array}$ & $\begin{array}{r}37 \\
136 \\
119\end{array}$ & $\begin{array}{l}0 \\
0.8 \\
0.8\end{array}$ & $\begin{array}{ccc}\text { Abnormal } & \text { popul } \\
0 & 5.4 & 5.4 \\
0 & 11.0 & 11.8 \\
0 & 6.0 & 6.8\end{array}$ & $\begin{array}{l}\operatorname{tion} \\
0 \\
11 \cdot 0 \\
8.4\end{array}$ & $\begin{array}{l}0 \\
1 \cdot 5 \\
0.8\end{array}$ & $\begin{array}{r}5 \cdot 4 \\
10 \cdot 2 \\
5 \cdot 0\end{array}$ & $\begin{array}{r}5 \cdot 4 \\
22 \cdot 0 \\
14 \cdot 0\end{array}$ \\
\hline
\end{tabular}

$\star$ Per cent of subjects classified in each lipoprotein type.

et al. (1967) in a North American population. As previously described, phenotypes were assigned in two ways: firstly, from levels of total cholesterol and triglyceride; secondly, using the additional information obtained from the LDL cholesterol levels. Results are shown in Table 4.

The initial classification indicated that type IV pattern occurred most frequently, 6.7 per cent of all subjects falling into this group. When LDL cholesterol levels were also considered, it was found that 6 subjects ( $21 \%$ of type IV group) could be reclassified as type IIB. The use of all available data indicates that 2.4 per cent of the 'normal' women compared with 7.5 per cent of the 'abnormal' group showed type IV hyperlipoproteinaemia.

When total cholesterol and triglyceride levels were used as the basis for classification, type II hyperlipoproteinaemia was present in 1 per cent. When LDL cholesterol levels were also considered, the frequency of type II patterns rose to 9.8 per cent

TABLE 3 Levels of total cholesterol, LDL cholesterol, and triglyceride (mmol/l) in apparently healthy women ${ }^{1}$

\begin{tabular}{|c|c|c|c|c|c|c|c|c|c|c|c|c|}
\hline $\begin{array}{l}\text { Age } \\
\text { group }\end{array}$ & $\begin{array}{l}\text { Toto } \\
\text { No. }\end{array}$ & $\begin{array}{l}\text { l population } \\
\text { Total } \\
\text { cholesterol }\end{array}$ & $\begin{array}{l}L D L \\
\text { cholesterol }\end{array}$ & $\begin{array}{l}\text { Trigly- } \\
\text { l ceride }\end{array}$ & $\begin{array}{l}\text { Nor } \\
\text { No. }\end{array}$ & $\begin{array}{l}\text { Total } \\
\text { cholesterol }\end{array}$ & $\begin{array}{l}L D L \\
\text { cholesterol }\end{array}$ & $\begin{array}{l}\text { Trigly- } \\
\text { l ceride }\end{array}$ & $\begin{array}{l}\text { Abn } \\
\text { No. }\end{array}$ & $\begin{array}{l}\text { ormal } \\
\text { Total } \\
\text { cholesterol }\end{array}$ & $\begin{array}{l}L D L \\
\text { l cholesterol }\end{array}$ & $\begin{array}{l}\text { Trigly- } \\
\text { l ceride }\end{array}$ \\
\hline $\begin{array}{l}30-39 \\
40-49 \\
50-59\end{array}$ & $\begin{array}{r}58 \\
188 \\
173\end{array}$ & $\begin{aligned} \star 5.2 & \pm 0.9 \\
5.6 & \pm 0.9 \\
\star \star \star 6.2 & \pm 1.0\end{aligned}$ & $\begin{array}{l}3.5 \pm 0.9 \\
3.9 \pm 0.9 \\
4.4 \pm 1.0\end{array}$ & $\begin{array}{l}0.9 \pm 0.4 \\
1.1 \pm 0.5 \\
1.2 \pm 0.6\end{array}$ & $\begin{array}{l}21 \\
52 \\
54\end{array}$ & $\begin{array}{r}5 \cdot 2 \pm 0.8 \\
5.5 \pm 0.7 \\
\star \star \star 6.2 \pm 1 \cdot 1\end{array}$ & $\begin{array}{l}3.6 \pm 0.9 \\
3.9 \pm 0.7 \\
4.5 \pm 1.0\end{array}$ & $\begin{array}{l}0.9 \pm 0.5 \\
0.9 \pm 0.4 \\
1.1 \pm 0.5\end{array}$ & $\begin{array}{r}37 \\
136 \\
119\end{array}$ & $\begin{array}{l}5.2 \pm 0.9 \\
5 \cdot 7 \pm 0.9 \\
6.3 \pm 1.0\end{array}$ & $\begin{array}{l}3.6 \pm 0.7 \\
3.9 \pm 0.9 \\
4.4 \pm 1.0\end{array}$ & $\begin{array}{r}0.9 \pm 0.4 \\
\star \star 1.2 \pm 0.5 \\
\star \star 1.3 \pm 0.6\end{array}$ \\
\hline
\end{tabular}

Significance of differences: $\star \mathbf{P}<0.02$ when compared with age 40 to $49 ; \star \star P<0.01$ when compared with normals of same age; $\star \star \star P<0.001$ when compared with age 40 to 49 .

${ }^{1}$ Mean $\pm S D$ is shown. 
(8.4\% type IIA and $1.4 \%$ type IIB). The type IIB group included subjects, initially classified as type IV, who showed a rise in LDL cholesterol but had normal total cholesterol, and also subjects with raised total cholesterol, triglycerides, and LDL cholesterol. From analysis of total cholesterol, triglyceride, and LDL cholesterol, 8.6 per cent of the 'normal' and 10.5 per cent of the 'abnormal' had a type II abnormality; this difference was not statistically significant.

\section{Male population}

Similar data were available for 103 male subjects aged between 40 and 59 years. Three subjects with chylomicra were assumed to be non-fasting and were excluded. Of the remaining 100 subjects, 18 were considered 'normal' and 82 'abnormal', using the previously defined criteria.

There was no significant difference in total cholesterol, LDL cholesterol, or triglycerides $(P>0.01)$ between the two age groups (Table 5). The small number of normal subjects did not allow comparison of subgroups.

Using total cholesterol and triglyceride levels as the basis for hyperlipoproteinaemia typing, it was found that 11 per cent of subjects had a type IV pattern. When LDL cholesterol levels were included, one subject was reclassified as type IIB, reducing the frequency of type IV to 10 per cent. It should be noted that obese subjects (32\%) have not been excluded, though previous experience suggests that these subjects are contributing to the presence of type IV pattern.

When total cholesterol levels alone were considered, no subject could be classified as type II. However, with the inclusion of LDL cholesterol levels 2 per cent of subjects had type IIA and 1 per cent type IIB abnormalities (Table 6).

\section{Discussion}

The frequency with which hyperlipoproteinaemia occurs in any population is dependent on arbitrary

TABLE 5 Levels of total cholesterol, LDL cholesterol, and triglycerides (mmol/l) in apparently healthy men ${ }^{1}$

\begin{tabular}{|c|c|c|c|c|}
\hline $\begin{array}{l}\text { Age } \\
\text { group }\end{array}$ & No. & $\begin{array}{l}\text { Total popu } \\
\text { Total } \\
\text { cholesterol }\end{array}$ & $\begin{array}{l}\text { tion } \\
\text { LDL } \\
\text { cholesterol }\end{array}$ & Triglyceride \\
\hline $\begin{array}{l}40-49 \\
50-59\end{array}$ & $\begin{array}{l}33 \\
67\end{array}$ & $\begin{array}{l}5.4 \pm 0.9 \\
5.7 \pm 0.9\end{array}$ & $\begin{array}{l}3.6 \pm 0.9 \\
3.8 \pm 0.9\end{array}$ & $\begin{array}{l}1.3 \pm 0.6 \\
1.3 \pm 0.5\end{array}$ \\
\hline
\end{tabular}

${ }^{1}$ Mean \pm SD is shown. limits selected by the investigators. Fredrickson et al. (1967) reported that the age-related levels for men and women followed a similar pattern and suggested that differences between the sexes could, for practical reasons, be ignored except in the case of HDL cholesterol. More recent evidence suggests that there may be significant differences in cholesterol and triglyceride levels between men and women (Brown and Daudiss, 1973; Lewis et al., 1974).

The present study showed a significant increase in total cholesterol, LDL cholesterol, and triglyceride with age in the female group. These data show that this rise is the result of an increase in LDL cholesterol, since no significant changes were found in VLDL and HDL cholesterol levels. Oral contraceptive preparations are associated with rises in triglycerides and HDL cholesterol, but none of our population was taking one of these; normal HDL values were found in all subjects during this study. It might be expected that a rise in triglyceride would be reflected in an increased VLDL cholesterol concentration. However, the absolute increases in triglyceride were such that as little as $0.078 \mathrm{mmol} / 1$ change in VLDL cholesterol concentration would be expected and this is beyond the precision of the methods used in this study.

These results for women contrast with our previous report on men in the same area, when no significant change in lipid levels was noted with age (Lorimer et al., 1974), a finding that is confirmed in our current smaller series. Results obtained on the male population corroborate those previously reported, in that total cholesterol does not rise with age over 40 years; in the present study, this was also found to be true of LDL cholesterol levels.

The triglyceride levels in men were significantly higher than those in women, both in the total population and in those considered normal by our criteria. These findings are in keeping with those reported by Brown and Daudiss (1973) and Wood

TABLE 6 Lipoprotein abnormalities in apparently healthy men

\begin{tabular}{|c|c|c|c|c|c|c|c|}
\hline \multirow[t]{2}{*}{$\begin{array}{l}\text { Age } \\
\text { group }\end{array}$} & \multirow[t]{2}{*}{$\begin{array}{l}\text { No. of } \\
\text { subjects }\end{array}$} & \multicolumn{3}{|c|}{$\begin{array}{l}\text { Classification by } \\
\text { total cholesterol } \\
\text { and triglyceride }\end{array}$} & \multicolumn{2}{|c|}{$\begin{array}{l}\text { Classification by } \\
\text { total and } L D L \\
\text { cholesterol and } \\
\text { triglyceride }\end{array}$} & \multirow[b]{2}{*}{ Total } \\
\hline & & ${ }_{A}^{T y p e ~}{ }_{B} I$ & $\begin{array}{l}\text { Type } \\
I V\end{array}$ & Total & ${ }_{A}$ Bpe $I I$ & Type & \\
\hline $\begin{array}{l}40-49 \\
50-59\end{array}$ & $\begin{array}{l}33 \\
67\end{array}$ & $\begin{array}{l}0 \\
0\end{array}$ & $\begin{array}{r}18 \cdot 2 \\
8 \cdot 9\end{array}$ & $\begin{array}{r}18 \cdot 2 \\
8 \cdot 9\end{array}$ & $\begin{array}{l}0 \\
3 \cdot 0\end{array}$ & $\begin{array}{r}15 \cdot 2 \\
8 \cdot 9\end{array}$ & $\begin{array}{l}18 \cdot 2 \\
11 \cdot 9\end{array}$ \\
\hline
\end{tabular}

*Per cent of subjects classified in each lipoprotein type. 
et al. (1972). It has been suggested that measurement of LDL cholesterol is more indicative of the risk of subsequent coronary heart disease than is measurement of total cholesterol. It seemed of importance to assess whether or not this measurement increased the yield of subjects at risk. In women, the initial classification of phenotypes, using the same upper limits of normal for total cholesterol and triglyceride as reported by Fredrickson et al. (1967), indicated type II abnormality in 1 per cent, with type IV being more frequent $(6.7 \%)$. However, classification using in addition LDL cholesterol levels increased the frequency of type II and decreased that of type IV. This increased frequency of type II (from 0.8 to $11 \%$ ) was especially obvious at age 40 to 49 years. It may be relevant that this is the age at which clinical manifestations of coronary heart disease begin to increase in women. Oliver (1974) has recently reported a series of 145 women with ischaemic heart disease who were under 45 years of age; when lipoprotein classification was undertaken, type IIA was the commonest abnormality found.

The significance of this apparent increase in the presence of type II abnormality when LDL cholesterol measurements are made is, however, not yet certain. It may be that the upper limits of normal used are too low for women or that our population differs from that reported from the United States and whose upper normal limits we have used. Nevertheless it is interesting to note that female populations studied in the United Kingdom and United States reveal similar age-related changes in the lipid levels measured, though absolute values differ (Brown and Daudiss, 1973). Alternatively, it may be that the use of LDL cholesterol values does indeed define a high risk group of subjects with respect to subsequent coronary heart disease. Long-term follow-up studies are required to confirm or refute this possibility.

The field survey was conducted in co-operation with management, trade unions, and employees of the Singer Manufacturing Co. Ltd., Clydebank, and supported by grants provided by the Renfrewshire King Edward Memorial Trust and the Scottish Home and Health Department.

\section{References}

Annan, W., and Isherwood, D. M. (1969). An automated method for the direct determination of total serum cholesterol. Fournal of Medical Laboratory Technology, 26, 202.

Ballantyne, F. B., and Jubb, J. S. (in preparation).
Beaumont, J. L., Carlson, L. A., Cooper, G. R., Fejfar, Z., Fredrickson, D. S., and Strasser, T. (1970). Classification of hyperlipidaemias and hyperlipoproteinaemias. Bulletin of the World Health Organization, 43, 891.

Blackburn, H. (1970). The pooling project report, Council on Epidemiology, American Heart Association. In Atherosclerosis, Proceedings of the Second International Symposium, p. 350 . Ed. by R. J. Jones. Springer, Berlin.

Brown, D. F., and Daudiss, K. (1973). Hyperlipoproteinemia: prevalence in a free-living population in Albany, New York. Circulation, 47, 558.

Burstein, M., Scholnick, H. R., and Morfin, R. (1970). Rapid method for the isolation of lipoproteins from human serum by precipitation with polyanions. Fournal of Lipid Research, 11, 583.

Carlson, L. A., and Böttiger, L. E. (1972). Ischaemic heartdisease in relation to fasting values of plasma triglycerides and cholesterol. Lancet, 1, 865 .

Fredrickson, D. S., Levy, R. I., and Lees, R. S. (1967). Fat transport in lipoproteins-an integrated approach to mechanisms and disorders. New England fournal of Medicine, 276, 34, 94, 148, 215, and 273.

Hawthorne, V. M., Gillis, C. R., and McLean, D. S. (1972). Monitoring health in Scotland. International fournal of Epidemiology, 1, 369.

Kannel, W. B., Castelli, W. P., Gordon, T., and McNamara, P. M. (1971). Serum cholesterol, lipoproteins, and the risk of coronary heart disease. Annals of Internal Medicine, 74, 1.

Kessler, G., and Lederer, H. (1965). Fluorometric measurement of triglycerides. In Automation in Analytical Chemistry, Teshnicon Symposia, 1965, p. 341. Ed. by L. T. Skeggs. Mediad, New York.

Keys, A. (1970). (Ed.) Coronary artery disease in seven countries. Circulation, $\mathbf{4 1}$ and $\mathbf{4 2}$, Suppl. 1.

Lees, R. S., and Hatch, F. T. (1963). Sharper separation of lipoprotein species by paper electrophoresis in albumincontaining buffer. Fournal of Laboratory and Clinical Medicine, 61, 518.

Lewis, B., Chait, A., Wootton, I. D. P., Oakley, C. M., Krikler, D. M., Sigurdsson, G., February, A., Maurer, B., and Birkhead, J. (1974). Frequency of risk factors for ischaemic heart-disease in a healthy British population: with particular reference to serum lipoprotein levels. Lancet, 1, 141.

Lorimer, A. R., Cox, F. C., Greaves, D. A., Jubb, J. S., Hawthorne, V. M., Morgan, H. G., and Lawrie, T. D. V. (1974). Prevalence of hyperlipoproteinaemia in apparently healthy men. British Heart fournal, 36, 192.

MRC Committee on the aetiology of chronic bronchitis (1965). Definition and classification of chronic bronchitis. Lancet, 1, 775.

Oliver, M. F. (1974). Ischaemic heart disease in young women. British Medical Fournal, 4, 253.

Rose, G. A., and Blackburn, H. (1968a). Cardiovascular survey methods. World Health Organization. Monograph Series, No. 56, p. 172.

Rose, G. A., and Blackburn, H. (1968b). Cardiovascular survey methods. World Health Organization. Monograph Series, No. 56, p. 91.

Slack, J. (1969). Risks of ischaemic heart disease in familial hyperlipoproteinaemic states. Lancet, 2, 1380.

Wood, P. D. S., Stern, M. P., Silvers, A., Reaven, G. M., and Groeben, J. von der (1972). Prevalence of plasma lipoprotein abnormalities in a free-living population of the Central Valley, California. Circulation, 45, 114.

Requests for reprints to Dr. A. R. Lorimer, University Department of Medical Cardiology, Royal Infirmary, Glasgow G4 OSF. 